\title{
Chemical and Nutritional Compositions of Flame of Forest (Delonix regia) Seeds and Seed Oil
}

\author{
O.A. Oyedeji ${ }^{\mathrm{a}, *}$, L.A. Azeez ${ }^{\mathrm{b}}$ and B.G. Osifade ${ }^{\mathrm{a}}$ \\ ${ }^{a}$ Department of Science Laboratory Technology, The Federal Polytechnic, Ilaro, Nigeria. \\ ${ }^{b}$ Analytical, Environmental and Nutritional Chemistry Research Laboratory, Department of Chemical Sciences, Osun State University, Osogbo, Nigeria.
}

Received 26 January 2016, revised 5 December 2016, accepted 14 December 2016.

\begin{abstract}
The seeds of Delonix regia were investigated for proximate, antinutrient, mineral, amino acid and vitamins compositions while the physicochemical properties, fatty acids and acylglycerols of its oil were also determined. Moisture, crude fibre, ash, crude fat, crude protein, carbohydrate, tannin, oxalate and saponin were $10.12 \pm 0.59 \%, 14.6 \pm 0.44 \%, 1.03 \pm 0.02 \%, 17.16 \pm 0.15 \%, 8.75 \pm$ $0.04 \%, 48.34 \%, 1.28 \pm 0.02 \mathrm{mg} \mathrm{g}^{-1}, 2.57 \pm 0.02 \mathrm{mg} \mathrm{g}^{-1}$, and $2.89 \pm 0.02 \mathrm{mg} \mathrm{g}^{-1}$, respectively. The seed contained $1604.0 \pm 0.1 \mathrm{mg}^{100 \mathrm{~g}^{-1}}$

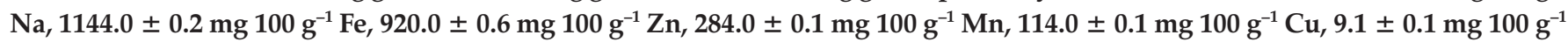

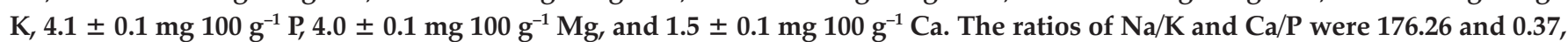
respectively. Glutamic acid (147.95 $\mathrm{mg} \mathrm{g}^{-1}$ protein) and methionine $\left(10.87 \mathrm{mg} \mathrm{g}^{-1}\right.$ protein) were the most and least abundant amino acids, respectively. The oil was liquid at room temperature, sweet-smelling, amber and had high saponification $(203.40 \pm 6.72 \mathrm{mg}$

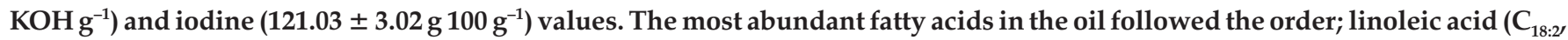
$37.1 \%)>$ palmitic acid $\left(\mathrm{C}_{16: 0}, 23.90 \%\right)>$ stearic acid $\left(\mathrm{C}_{18: 0 \%} 8.20 \%\right)>$ linolenic $\left(\mathrm{C}_{18: 3}, 7.6 \%\right)>$ oleic $\left(\mathrm{C}_{18: 1} \Delta_{9}, 4.91 \%\right)>$ ricinoleic acid $\left(\mathrm{C}_{18: 1}, 4.50 \%\right)$. The ratio of saturated to unsaturated fatty acids was 0.83 . Vitamin $\mathrm{E}\left(33.68 \mathrm{mg} 100 \mathrm{~g}^{-1}\right)$ and triacylglycerols $(96.62 \%)$ accounted for the highest contributions to vitamins and acylglycerols, respectively, in the oil. These results showed that the seeds were nutritive and good for both nutrition and industrial uses.
\end{abstract}

KEYWORDS

Delonix regia seed, chemical composition, nutritional composition, seed oil.

\section{Introduction}

Oils from vegetable sources especially their seeds have recently gained prominence and attention because of their wide range of uses. They are good sources of food and raw materials for industries for the production of lubricants, fuel for paraffin lamps, additives for paint formulation and soap production. ${ }^{1,2}$ Due to continuous demands for edible and industrial oils, various sources of oil, especially from seeds of relatively neglected plants that are in abundance in our locality, are continuously being investigated to supplement the existing ones. One of such plants is Delonix regia.

Delonix regia is a legume and belongs to the family Caesalpiniaceae. It is a beautiful, semi-deciduous tree known as flame of forest in Nigeria and grows to heights of about 18 metres. It can be easily propagated from seeds but take a long time to germinate. Leaflets are less than $12 \mathrm{~mm}$ long with very numerous flowers with long stalks. Leaflets are opposite and flowers are conspicuous and scarlet. The fruits are long pods, which dangle from the branches and are green and flaccid when young and later turn dark brown and hard when matured. On ripening, the mature fruit splits open into two halves revealing the elongated hard seeds. ${ }^{3-8} D$. regia leaves and seeds have been reported to possess anti-inflammatory, anti-microbial, anti-ulcer and antioxidant properties. ${ }^{5,6}$ Pharmacological, phytochemical and proximate investigation of $D$. regia showed that it contains bioactive compounds and essential minerals such as tannin, saponin, phenolics, flavonoids, reducing sugars, triterpenoids, anthraquinones, amino acids, alkaloids, sodium, potassium, calcium, phosphorus and iron. ${ }^{9,10}$

* To whom correspondence should be addressed.

E-mail: olalekan.oyedeji@ federalpolyilaro.edu.ng
Delonix regia leaves, roots, and seeds have been extensively used in the treatment of many diseases and ailments but only the immature seeds have been found edible because the mature seeds are reportedly toxic due to their antinutrient contents. ${ }^{6}$ Thus, there is a need to carry out research on its mature seed, may be it will be useful in the industries and for compounding animal feeds. The comprehensive reporting of the oil from these seeds has not been done. Thus, this study investigated the proximate, amino acid, and vitamins composition of mature seeds and characterized the oil extracted from them for fatty acids, acylglycerols and amino acids for its usefulness in the industries and animal feeds.

\section{Materials and Methods}

\subsection{Seed Samples}

Mature pods of $D$. regia were collected from a tree within the premises of the Federal Polytechnic, Ilaro $\left(6.89^{\circ} \mathrm{N}, 3.02^{\circ} \mathrm{E}\right)$ between February and March, 2013. The seeds were removed from the pods, washed with distilled-deionized water and then oven-dried at $60^{\circ} \mathrm{C}$. The dried seeds were pulverized using a blender, sieved and kept in an airtight container for further analysis.

\subsection{Proximate and Antinutrient Composition}

Standard methods of Association of Analytical Chemists ${ }^{11}$ were used for the analysis of moisture, crude fibre, ash, crude fat, tannin, saponin and oxalate contents. Nitrogen was determined using micro-Kjeldahl method. Crude protein content was estimated by multiplying $\% \mathrm{~N}$ by a factor, 6.25 . All analyses were carried out in triplicate. Carbohydrate content was determined by difference. 


\subsection{Macro and Micro Mineral Elements}

The micro and macro mineral contents such as potassium (K), magnesium $(\mathrm{Mg})$, calcium $(\mathrm{Ca})$, sodium $(\mathrm{Na})$, manganese $(\mathrm{Mn})$, iron $(\mathrm{Fe})$, copper $(\mathrm{Cu})$ and zinc $(\mathrm{Zn})$ were determined in triplicate using Atomic Absorption Spectrophotometer (Buck 210 VGP).

\subsection{Amino Acid Composition}

Amino acid composition of the seeds was determined using modified method of Association of Analytical Chemists. ${ }^{12} 10 \mathrm{~g}$ of dried pulverized sample was weighed into a $250 \mathrm{~mL}$ conical flask. This was defatted by extracting the fat with $30 \mathrm{~mL}$ petroleum ether three times using soxhlet apparatus. The defatted flour was thereafter hydrolyzed with $6 \mathrm{~N} \mathrm{HCl}$ acid for $24 \mathrm{~h}$ at $110^{\circ} \mathrm{C}$. The amino acid content was recovered by extracting with $30 \mathrm{~mL}$ dichloromethane three times. This was then concentrated to $1 \mathrm{~mL}$ for gas chromatography (HP 6890) coupled with pulse flame photometric detector (GC-PTFD) analysis. $1 \mu \mathrm{L}$ was injected into GC-PFPD with a column HP5 $(30 \mathrm{~m} \times 0.25 \mu \mathrm{m} \times$ $0.255 \mathrm{~mm}$ id) to obtain individual peaks of amino acids. The carrier gas hydrogen and column was initially at $60^{\circ} \mathrm{C}$, first ramp at $8{ }^{\circ} \mathrm{C}$ for $20 \mathrm{~min}$ and maintained for $2 \mathrm{~min}$. The second ramp at $12{ }^{\circ} \mathrm{C}$ min $^{-1}$ for 6 min was constant for $2 \mathrm{~min}$.

\subsection{Extraction of Seed Oil}

The method of Nehdi et al. ${ }^{2}$ was used for extraction. The powdered seeds of $D$. regia were extracted with $400 \mathrm{~mL}$ hexane using a soxhlet extraction apparatus for $8 \mathrm{~h}$. The hexane was recovered using a rotary vacuum evaporator at $40-50{ }^{\circ} \mathrm{C}$.

\subsubsection{Physicochemical Parameters}

Iodine value was determined using ISO $396^{13}$ and saponification value using ISO 3657 methods. ${ }^{14}$ Refractive index was determined using a refractometer (Spectronic instruments Model no. 334610) and density was measured using density bottle method.

\subsubsection{Fatty Acid Composition}

The fatty acid composition was determined using the method of Nehdi et al. ${ }^{2}$ with modification. $1 \mu \mathrm{L}$ of oil converted to methyl ester was injected into GC coupled with MS (Shimadzu gcms-QP2010) with a column HP $(30 \mathrm{~m} \times 0.25 \mu \mathrm{m} \times 0.255 \mathrm{~mm}$ id) to obtain individual peaks of the fatty acid methyl esters. The carrier gas was helium and the injector temperature was $250{ }^{\circ} \mathrm{C}$ with splitless modes. The column temperature was initially at $80{ }^{\circ} \mathrm{C}$ held for $1 \mathrm{~min}$ and increased at the rate of $10{ }^{\circ} \mathrm{C} \mathrm{min}^{-1}$ to $200{ }^{\circ} \mathrm{C}$ held for $2 \mathrm{~min}$ and held at the rate of $20^{\circ} \mathrm{C} \mathrm{min}^{-1}$ to $300{ }^{\circ} \mathrm{C}$ for $8 \mathrm{~min}$.

\subsubsection{Acylglycerol Composition}

The method of ASTM D6584 ${ }^{15}$ was used for determination of acylglycerol composition. $50 \mathrm{~mL}$ of the extracted oil content of the sample was saponified for $5 \mathrm{~min}$ at $95^{\circ} \mathrm{C}$ with $3.4 \mathrm{~mL}$ of the $0.5 \mathrm{M}$ methanolic $\mathrm{KOH}$ and neutralized using $0.7 \mathrm{M} \mathrm{HCl} .3 \mathrm{~mL}$ of the $14 \% \mathrm{BF}_{3}$ in methanol was added and the mixture was heated for $5 \mathrm{~min}$ at $90^{\circ} \mathrm{C}$ to achieve complete methylation. The fatty acid methyl esters were extracted three times from mixture with redistilled n-hexane. The content was concentrated to $1 \mathrm{~mL}$ for gas chromatography coupled with flame ionization detector analysis. $1 \mu \mathrm{L}$ was injected into the injection port of GC (HP 6890 powered with HP ChemStation) equipped with flame ionization detector (FID). The carrier gas was helium in a column EliteBiodiesel M with dimension $14 \mathrm{~m} \times 530 \mu \mathrm{m} \times 0.16 \mu \mathrm{m}$. The injector temperature was $60{ }^{\circ} \mathrm{C}$ while the detector temperature was $380^{\circ} \mathrm{C}$. The column temperature was initially at $60^{\circ} \mathrm{C}$ held for $2 \mathrm{~min}$ and increased at the rate of $10{ }^{\circ} \mathrm{C} \mathrm{min}{ }^{-1}$ to $200{ }^{\circ} \mathrm{C}$ held for $2 \mathrm{~min}$ and held at the rate of $8^{\circ} \mathrm{C} \mathrm{min}^{-1}$ to $300{ }^{\circ} \mathrm{C}$ for $5 \mathrm{~min}$.

\subsubsection{Vitamin Composition}

Vitamins (A, D, E, K, $\mathrm{B}_{1}, \mathrm{~B}_{2}, \mathrm{~B}_{3}, \mathrm{~B}_{5}, \mathrm{~B}_{6}, \mathrm{~B}_{9}$ and C) in the seeds were determined using Association of Analytical Chemists ${ }^{12}$ method. The seeds were homogenized and extracted with $0.1 \mathrm{M} \mathrm{H}_{2} \mathrm{SO}_{4}$ $\left(15 \mathrm{~min}, 120-123^{\circ} \mathrm{C}\right)$. The resulting slurry was treated with $8 \mathrm{~mL}$ of $2 \mathrm{M}-\mathrm{CH}_{3} \mathrm{COONa}$ buffer and thereafter digested with $10 \%$ amylase. The digest obtained was centrifuged in methanol and concentrated to $1 \mathrm{~mL}$ for the chromatographic analysis using gas chromatography (HP 6890) coupled with pulse flame photometric detector (GC-PFPD). $1 \mu \mathrm{L}$ of the extract was injected into the injection port with a column $\mathrm{HP}(30 \mathrm{~m} \times 0.25 \mu \mathrm{m} \times 0.255 \mathrm{~mm}$ id $)$ to obtain individual peaks of each vitamin. The carrier gas was nitrogen and the inlet temperature was $250{ }^{\circ} \mathrm{C}$ while the detector temperature was $320^{\circ} \mathrm{C}$. The column temperature was initially at $50{ }^{\circ} \mathrm{C}$ held for $2 \mathrm{~min}$ and increased at the rate of $10^{\circ} \mathrm{C} \mathrm{min}-1$ for $20 \mathrm{~min}$, maintained for $4 \mathrm{~min}$ and held at the rate of $20^{\circ} \mathrm{C} \mathrm{min}^{-1}$ to $320{ }^{\circ} \mathrm{C}$ for $2 \mathrm{~min}$.

\section{Results and Discussion}

\subsection{Proximate Composition}

Proximate composition of $D$. regia is presented in Table 1 . Moisture, crude fibre, ash, crude fat, crude protein and carbohydrate are $10.12 \pm 0.59 \%, 14.6 \pm 0.44 \%, 1.03 \pm 0.02 \%, 17.16 \pm 0.15 \%$, $8.75 \pm 0.04 \%$ and $48.34 \%$, respectively. The results obtained in this study for moisture, crude fibre, crude fat and carbohydrate are higher than values obtained for $D$. regia by Bake et al. ${ }^{8}$ and Amata and $\mathrm{Nwagu}^{6}$ but ash and crude protein are lower than what they obtained. The difference in results could be due to variation in species, environmental and soil conditions. ${ }^{16}$ Low moisture content of these seeds is an indicator that the seeds

Table 1 Proximate, mineral and antinutrient contents of Delonix regia seeds.

\begin{tabular}{|c|c|}
\hline Parameter & $\begin{array}{l}\text { Proximate } \\
\text { composition/\% }\end{array}$ \\
\hline Moisture & $10.12 \pm 0.59$ \\
\hline Crude Fibre & $14.60 \pm 0.44$ \\
\hline Fat & $17.16 \pm 0.15$ \\
\hline Ash & $1.03 \pm 0.02$ \\
\hline Crude Protein & $8.75 \pm 0.04$ \\
\hline Carbohydrate & $48.34 \pm 2.22$ \\
\hline Minerals & mg $100 \mathrm{~g}^{-1}$ \\
\hline Potassium & $9.10 \pm 0.1$ \\
\hline Magnesium & $4.00 \pm 0.1$ \\
\hline Calcium & $1.5 \pm 0.1$ \\
\hline Phosphorus & $4.1 \pm 0.1$ \\
\hline Sodium & $1604.0 \pm 0.1$ \\
\hline Iron & $1144.0 \pm 0.2$ \\
\hline Zinc & $920.0 \pm 0.6$ \\
\hline Manganese & $284.0 \pm 0.1$ \\
\hline Copper & $114.0 \pm 0.1$ \\
\hline Antinutrient content & $\mathrm{mg} \mathrm{g}^{-1}$ \\
\hline Tannin & $1.28 \pm 0.02$ \\
\hline Oxalate & $2.57 \pm 0.02$ \\
\hline Saponin & $2.89 \pm 0.02$ \\
\hline
\end{tabular}

All values are means of triplicate determinations \pm standard deviation. 
may not support the growth of microorganisms as high moisture content hastens food spoilage and enhances microbial growth. ${ }^{17,18}$ The fat content of the seed indicates that it could be a potential source of biodiesel feedstock. ${ }^{19}$ The ash and protein contents of this seed show that they are better sources of dietary minerals and protein than Xylocarpus moluccensis seeds. ${ }^{19}$ Carbohydrate content of $D$. regia seed is comparable with the results obtained by Coimbra and Jorge ${ }^{19}$ for fruits of Syagrus oleracea, Syagrus romanzoffiana and Acrocomia aculeate. This indicates that the seeds are rich in carbohydrate because it meets recommended dietary values of $40 \%$ for children and adults. ${ }^{18-20}$

\subsection{Antinutrient Contents}

Results of antinutrient contents of $D$. regia seed (Table 1 ) are tannin $1.28 \pm 0.02 \mathrm{mg} \mathrm{g}^{-1}$, oxalate $2.57 \pm 0.02 \mathrm{mg} \mathrm{g}^{-1}$, and saponin $2.89 \pm 0.02 \mathrm{mg} \mathrm{g}^{-1}$. The values were lower compared to the values reported for tannin and phytate in Colocasia esculenta according to Lewu et al. ${ }^{21}$, for Colocasia esculenta L. and saponin reported by Jukanti et al. ${ }^{22}$ for Cicer arietinum L. but have higher oxalate content than values obtained by Amata and Nwagu ${ }^{6}$ for D. regia. Oxalate has been implicated in the formation of kidney stones and a decrease in calcium absorption but consumption of seeds of low oxalate content such as $D$. regia may not induce any of these. Tannin content of this seed is also lower than the critical value of $9.0 \mathrm{mg} \mathrm{g}^{-1}$ that could induce tannin toxicity. ${ }^{23}$ It has been reported that tannins complex proteins resulting in the reduction of protein digestibility and palatability. ${ }^{21}$ The presence of saponin in $D$. regia shows that it could provide a chemopreventive measure as it has been reported that saponin lowers blood cholesterol, inhibits the growth of cancerous cells and enhances immune system however the low content in this seed shows that it may not pose any danger when the seed is consumed..$^{21,22}$

\subsection{Mineral Composition}

The trend of the abundance of mineral concentration in the seeds of $D$. regia (Table 1 ) in decreasing order is as follows $\mathrm{Na}>\mathrm{Fe}>\mathrm{Zn}>\mathrm{Mn}>\mathrm{Cu}>\mathrm{K}>\mathrm{M}>\mathrm{P}>\mathrm{Ca}$. Results obtained in the current study showed lower concentrations of $\mathrm{Mn}, \mathrm{Cu}, \mathrm{K}, \mathrm{Mg}$ and $\mathrm{Ca}$ but higher values of $\mathrm{Na}, \mathrm{Fe}$ and $\mathrm{Zn}$ than results of mineral contents obtained by Amata and $\mathrm{Nwagu}^{6}$ for $D$. regia seeds while it is higher than the results obtained for fruits of Antheraea pernyi and leaves of Cnidoscolus aconitifolius. Macro and micro elements are necessary for normal physiological function, the deficiency of which causes serious metabolic abnormalities and the increase of which leads to toxicity, so their presence in $D$. regia shows it is a good source for essential minerals. ${ }^{25} \mathrm{High} \mathrm{Fe}, \mathrm{Zn}, \mathrm{Mn}$ and $\mathrm{Cu}$ contents of the seed indicate it is a good source of these minerals needed in blood formation and normal functioning of the immune system. Low levels of $\mathrm{Ca}, \mathrm{Mg}$ and $\mathrm{P}$ show that the seed may not be a good source of minerals for bone formation. ${ }^{20,26}$

$\mathrm{Na} / \mathrm{K}$ ratio for $D$. regia seed in this study is 176.26 and when this ratio is higher than 1 in diet, such diets have been linked with increased risk of hypertension and cardiovascular disease (CVD)-related mortality. ${ }^{26}$ For the seeds to provide the required $\mathrm{Na} / \mathrm{K}$ ratio, it has to be complemented with other food items rich in $\mathrm{K}$. In this study, the seeds of $D$. regia analyzed for minerals have $\mathrm{Ca} / \mathrm{P}$ ratio of 0.37 , this shows that the seeds are not a good source of minerals for bone formation. A diet with $\mathrm{Ca} / \mathrm{P}$ ratio higher than one is considered a good source of minerals for bone formation but with a ratio less than 0.5 is considered a poor source. ${ }^{27}$

\subsection{Amino Acid Composition}

The results of amino acid composition of D. regia seed are presented in Table 2. D. regia contained seventeen known amino acids including all essential amino acids (EAAs) and sulphurcontaining amino acids. Glutamic acid was the most abundant while methionine was the least abundant. The percentage of EAAs in the total amino acids is $35.48 \%$ and the ratio of EAAs to non-EAAs is 0.55 which is close to 0.6 recommended by FAO/ WHO. ${ }^{29,30}$ The percentages of savoury amino acids (glutamic acid) and sweet amino acids (glycine and alanine) to the total amino acids were $16.82 \%$ and $17.97 \%$, respectively. The high content of glutamic acid suggests that $D$. regia has a very good flavouring agent used in food preparation. This is also beneficial because glutamic acid is involved in the synthesis and metabolism of nucleotides and amino acids. ${ }^{31}$ Total EAAs in D. regia (312.05 mg g-1 protein) is lower than EAAs of A. pernyi (406.2 mg $\mathrm{g}^{-1}$ protein) reported by Zhou and Han. ${ }^{26}$ The EAAs of $D$. regia is comparable with $\mathrm{FAO} / \mathrm{WHO}$ reference pattern established for humans: 40, 70, 55, 35, 60, 40, 10 and 50 for Isoleucine, Leucine, Lysine, (Methionine + Cysteine), (Phenylalanine + Tyrosine), Threonine, Tryptophan and Valine, respectively, but for Tryptophan which was deficient. Also, the EAAs are comparable with the reference $(\mathrm{FAO} / \mathrm{WHO} / \mathrm{UNU})^{32}$ required for pre-school children: $34,35,25,28,66,63$ and $58 \mathrm{mg} \mathrm{g}^{-1}$ protein for Threonine, Valine, (Methionine + Cysteine), Isoleucine, Leucine, (Phenylalanine + Tyrosine) and Lysine.

The results of amino acid composition in $D$. regia seed shows that it could be used as a supplement for protein and amino acid deficiency as well as in compounding animal feeds. ${ }^{16,26}$

Table 2 Amino acid composition of Delonix regia seed.

\begin{tabular}{lr}
\hline Amino acid & $\mathrm{mg} \mathrm{g}^{-1}$ Protein \\
\hline Essential amino acids & 49.88 \\
Isoleucine & 77.73 \\
Leucine & 32.78 \\
Lysine & 10.87 \\
Methionine & 18.21 \\
Cystine & 41.84 \\
Phenylalanine & 25.87 \\
Tyrosine & 40.50 \\
Threonine & 54.87 \\
Valine & \\
Non-essential amino acids & 80.69 \\
Glycine & 77.33 \\
Alanine & 54.60 \\
Serine & 54.17 \\
Proline & 68.05 \\
Aspartic acid & 147.95 \\
Glutamatic acid & 32.82 \\
Histidine & 66.14 \\
Arginine & \\
\hline
\end{tabular}

\subsection{Physicochemical Properties}

Physicochemical properties of $D$. regia seed oil are presented in Table 3 . The seeds contained $17.16 \%$ of oil. They have higher oil content than Albizia julibrissin $\left(10.50 \%\right.$ ) reported by Nehdi et al., ${ }^{2}$ Phoenix canariensis $(10.36 \%)$ reported by $\mathrm{Nehdi}^{33}$ and D. regia reported by Arora et al. ${ }^{4}$ At room temperature, D. regia oil was a liquid, amber in colour and sweet-smelling. Iodine value was

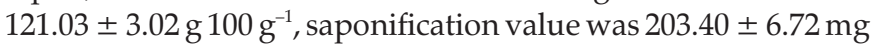
$\mathrm{KOH} \mathrm{g}{ }^{-1}$, refractive index $\left(25^{\circ} \mathrm{C}\right)$ was 1.47 and density was $0.97 \mathrm{~g} \mathrm{~cm}^{-3}$.

These results are comparable with the results of $A$. julibrissin reported by Nehdi et al., ${ }^{2}$ Phoenix canariensis $(10.36 \%$ ) reported by $\mathrm{Nehdi}^{33}$ and D. regia reported by Arora et al. ${ }^{4}$ with the excep- 
Table 3 Physicochemical properties of Delonix regia seed oil.

\begin{tabular}{ll}
\hline Colour & Amber \\
Odour & Sweat-smelling \\
State at room temperature & Liquid \\
Saponification value $/ \mathrm{mg} \mathrm{KOH} \mathrm{g}^{-1}$ & $203.40 \pm 6.72^{\mathrm{a}}$ \\
Iodine value $/ \mathrm{g} 100 \mathrm{~g}^{-1}$ & $121.03 \pm 3.02^{\mathrm{b}}$ \\
Refractive Index @ $25^{\circ} \mathrm{C}$ & 1.47 \\
Density & 0.97 \\
\hline
\end{tabular}

$\mathrm{a}$ and $\mathrm{b}$ are means of triplicate determinations \pm standard deviation.

tion of density. Saponification and iodine values of $D$. regia indicate that the oil contains normal glycerides, low unsaturation and will be very good for the production of soaps and shampoos. ${ }^{2}$ Refractive index in this study shows that the oil has lower degree of unsaturation compared with $A$. julibrissin reported by Nehdi et al., ${ }^{2}$ The result for density shows that the oil contains large molecular sizes of triacylglycerides. ${ }^{34}$

\subsection{Fatty Acid Composition of the Seed Oil}

The results of fatty acid in $D$. regia seeds are presented in Table 4 . The oil contained high level of linoleic acid $\left(\mathrm{C}_{18: 2}, 37.1 \%\right)$ followed by palmitic acid $\left(\mathrm{C}_{16: 0}, 23.90 \%\right)$, stearic acid $\left(\mathrm{C}_{18: 0}\right.$, $8.20 \%)$, linolenic $\left(\mathrm{C}_{18: 3}, 7.6 \%\right)$, oleic $\left(\mathrm{C}_{18: 1} \Delta^{9}, 4.91 \%\right)$ and ricinoleic acid $\left(\mathrm{C}_{18: 1}, 4.50 \%\right)$. The total saturated fatty acid (SAFA) was $44.71 \%$ and total unsaturated fatty acid was $54.11 \%$ (Monounsaturated $9.41 \%$ and Polyunsaturated $44.70 \%$ ). Polyunsaturated/saturated fatty acid of ratio 0.999 makes it inferior to A. julibrissin (2.96). This confirms that the degree of unsaturation in $D$. regia is lower than in A. julibrissin as also revealed by refractive index. This equally shows that it is favourable for consumption to reduce serum cholesterol, atherosclerosis and prevention of heart diseases..$^{35}$ Values obtained for palmitic and stearic were higher but values for oleic, linoleic, linolenic and arachidic were lower than results obtained by Arora et al. for the seed. ${ }^{4}$

Nutritional and industrial characteristics of oils are enhanced by the amount of fatty acid components. The linoleic acid which is the most abundant in D. regia is indispensable for the healthy growth of human skin and it makes the oil a valuable component for the production of food and in cosmetic applications. ${ }^{4,36}$ Oleic acid is very important in nervous cell construction but its percentage is low in this oil, thus, $D$. regia oil may not be much desirable in terms of nutrition. ${ }^{35}$ However, D. regia oil will provide good resistance to oxidative rancidity due to its high SAFA content. $^{33}$

\subsection{Acylglycerol Composition}

The percentages of monoacylglycerols (MAGs), diacylglycerols (DAGs) and triacylglycerols (TAGs) are presented in Table 4 . Triacylglycerols are the most abundant with $96.62 \%$. The results were similar to those reported for chickpea by Jukanti et al. ${ }^{22}$ The percentage of triacyglycerol in this oil reflects a good relationship between fatty acid and acylglycerols. ${ }^{2}$

\subsection{Vitamin Profile}

Vitamin contents of D. regia are presented in Table 5. Fat-soluble vitamins contents were higher than water soluble vitamins. In all, vitamin $\mathrm{E}$ was the most abundant. Vitamin $\mathrm{E}$ content in $D$. regia is higher than vitamin $E$ contents in Tamarindus indica and Citrullus vulgaris. Vitamin $\mathrm{E}$ is a fat-soluble vitamin which is known to have several biological functions of which the most important are its antioxidant function and prevention of lipid peroxidation. ${ }^{37,38}$
Table 4 Fatty acid and glyceride compositions of Delonix regia seed oil.

\begin{tabular}{ll}
\hline Fatty acid & $\%$ \\
\hline Saturated & \\
$\mathrm{C}_{12: 0}$ & 0.66 \\
$\mathrm{C}_{14: 0}$ & 1.23 \\
$\mathrm{C}_{16: 0}$ & 23.9 \\
$\mathrm{C}_{17: 0}$ & 2.02 \\
$\mathrm{C}_{18: 0}$ & 8.20 \\
$\mathrm{C}_{19: 0}$ & 1.14 \\
$\mathrm{C}_{20: 0}$ & 2.58 \\
$\mathrm{C}_{21: 0}$ & 0.82 \\
$\mathrm{C}_{22: 0}$ & 1.46 \\
$\mathrm{C}_{23: 0}$ & 0.95 \\
$\mathrm{C}_{24: 0}$ & 0.82 \\
$\mathrm{C}_{25: 0}$ & 0.41 \\
$\mathrm{C}_{26: 0}$ & 0.52 \\
Monounsaturated & \\
$\mathrm{C}_{18: 1}$ & 4.5 \\
$\mathrm{C}_{18: 1} \Delta^{9}$ & 4.91 \\
Polyunsaturated & \\
$\mathrm{C}_{18: 2} \Delta^{9,12}$ & 37.10 \\
$\mathrm{C}_{18: 3} \Delta^{9,12,15}$ & 7.6 \\
$\mathrm{C}_{20: 3} \mathrm{D}^{7,10,13}$ & 1.17 \\
SAFA & 44.71 \\
MUFA & 9.41 \\
PUFA & 44.70 \\
Others & 1.18 \\
Acylglycerols & \\
MAGs & 2.03 \\
DAGs & 1.35 \\
TAGs & 96.62 \\
\hline & \\
\hline
\end{tabular}

SAFA, saturated fatty acid; MUFA, monounsaturated fatty acid; PUFA, polyunsaturated fatty acid; MAGs, monoacylglycerols; DAGs, diacylglycerols; TAGs, triacylglycerols.

Table 5 Vitamin contents of Delonix regia seed.

\begin{tabular}{ll}
\hline Vitamins & ${\mathrm{mg} 100 \mathrm{~g}^{-1}}^{\text {Fat-soluble }}$ \\
$\mathrm{A}$ & 0.41 \\
$\mathrm{D}$ & 0.23 \\
$\mathrm{E}$ & 33.68 \\
$\mathrm{~K}$ & 0.05 \\
Water-soluble & \\
$\mathrm{B}_{3}$ & $5.71649 \times 10^{-6}$ \\
$\mathrm{~B}_{6}$ & $4.92179 \times 10^{-6}$ \\
$\mathrm{~B}_{5}$ & $8.59820 \times 10^{-7}$ \\
$\mathrm{~B}_{1}$ & $3.02199 \times 10^{-6}$ \\
$\mathrm{~B}_{2}$ & $1.66783 \times 10^{-6}$ \\
$\mathrm{~B}_{9}$ & $7.30487 \times 10^{-6}$ \\
$\mathrm{C}^{-9}$ & $8.37665 \times 10^{-9}$ \\
\hline
\end{tabular}

\section{Conclusion}

This study has investigated $D$. regia seeds for proximate composition, antinutrient contents and mineral composition while the seed oil was investigated for vitamins, fatty acid, acylglycerol, amino acid composition and physicochemical properties. It was concluded that the seeds are a good source of oil, energy-rich, good for consumption and can be used as protein supplement but may pose cardiovascular risk due to its high sodium-to-potassium ratio. The seed oil contains essential fatty acids, acylglycerols and vitamins needed for nutrition and production of soaps, shampoos and as a biodiesel feedstock. 


\section{References}

1 E.O. Aluyor, C.E. Ozigagu, O.I. Oboh and P. Aluyor, Chromatographic analysis of vegetable oils: a review, Sci. Res. Essay, 2009, 4, 191-197.

2 I. Nehdi, S. Omri, M.I. Khalil and S.I. Al-Resayes, Characteristics and chemical composition of date palm (Phoenix canariensis) seeds and seed oil, Ind. Crops Prod., 2010, 32, 360-365.

3 F. Adje, Y.F. Lozano, E. Meudec, P. Lozano, A. Adima, G.A. N'zi and E.M. Gaydou, Anthocyanin characterization of pilot plant water extracts of Delonix regia flowers, Molecules, 2008, 13, 1238-1245.

4 A. Arora, R. Sen and J. Singh, Fatty acid composition of Delonix regia (Gulmohar) seed oil from arid zone of Rajasthan, J. Indian Coun. Chem., 2010, 27, 150-152.

5 P.M.J. Rani, P.S.M. Kannan and S. Kumaravel, Screening of antioxidant activity, total phenolics and gas chromatograph and mass spectrometer (GC-MS) study of Delonix regia, Afr. J. Biochem. Res., 2011, 5 , 341-347.

6 I.A. Amata and K.M. Nwagu, Comparative evaluation of the nutrient profile of the seeds of four selected tropical plants and maize, Int. J. Appl. Biol. Pharm. Tech, 2013, 4, 200-204.

7 I.B. Kaga, Biological and carcass characteristics of rabbits fed Delonix regia meal diets, Biol. Sys., 2013, 2, 120

8 G.G. Bake, E.L. Martins and S.O.E. Sadiku, Nutritional evaluation of varying levels of cooked flamboyant seed meal (Delonix regia) on the growth performance and body composition of Nile tilapia (Oreochromis niloticus) fingerlings, Agric., Forest. Fish., 2014, 3, 233-239.

9 A.R. Kumar, R. Shaik and D. Yeshwanth, Phytochemical evaluation of Delonix regia, Samanea saman and Bauhinia variegata, Int. J. Res. Pharm. Chem., 2013, 3, 768-772.

10 S.P. Roy, K. Prajapati, R. Gupta, D. Bhadra, N. Patel, A. Batiwala, G. Sonara, N. Gheewala and T. Kannadasan, Evaluation of anti-ulcer effects of ethanolic extract of Delonix regia flower, Indian J. Res. Pharm. Biotech., 2013, 1, 440-445.

11 AOAC, 1990, Official Methods of Analysis, 15th edn., The Association of Official Analytical Chemists, Arlington, USA.

12 AOAC, 2006, Official Methods of Analysis, 18th edn., The Association of Official Analytical Chemists, Arlington, USA.

13 ISO, 1996, Animal and vegetable fats and oils, in ISO 3961, Determination of Iodine Value, International Organization for Standardization.

14 ISO, 2002, Animal and vegetable fats and oils, in ISO3657, Determination of Saponification Value, International Organisation for Standardisation.

15 D6584, 2003, Test Method for Determination of Free and Total Glycerides in B-100 Biodiesel Methyl Esters by Gas Chromatography, ASTM International, West Conshohocken, PA, USA.

16 R. Horax, N. Hettiarachchy, A. Kannanand A.P. Chen, Proximate composition and amino acid and mineral contents of Mormordica charantia L. pericarp and seeds at different maturity stages, Food Chem., 2010, 122, 1111-1115.

17 L. Azeez, M.D. Adeoye, O.T. Ganiyu, I.O. Abdulsalami, T.A. Majolagbe and A.T. Lawal, Influence of microbial contamination on the antioxidant composition and freeradical scavenging effects of fresh and decaying spices, Fountain J. Nat. App. Sci., 2012, 1, 55-64.

18 E.D. Fagbohun, A.O. Egbebi and O.U. Lawal, Phytochemical screening, proximate analysis and in-vitro antimicrobial activities of methanolic extract of Cnidoscolus aconitifolius leaves, Int. J. Pharm. Sci. Rev. Res., 2012, 13, 28-33

19 S. Gunawan, R. Darmawan, M. Nanda, A.M. Setiawan and H. Fansuri, Proximate composition of Xylocarpus moluccensis seeds and their oils, Ind. Crops Prod., 2013, 41, 107-112.
20 M.C. Coimbra and N. Jorge, Proximate composition of guariroba (Syagrus oleracea), jerivá (Syagrus romanzoffiana) and macaúba (Acrocomia aculeata) palm fruits, Food Res. Int., 2011, 44, 2139-2142.

21 M.N. Lewu, P.O. Adebola and A.J. Afolayan, Effect of cooking on the mineral contents and anti-nutritional factors in seven accessions of Colocasia esculenta (L.) Schott growing in South Africa, J. Food Comp. Anal., 2010, 23, 389-393.

22 A.K. Jukanti, P.M. Gaur, C.L.L Gowda and R.N. Chibbar, Nutritional quality and health benefits of chickpea (Cicer arietinum L.): a review, Brit. J. Nutr., 2012, 108, 11-26.

23 G. Oboh and A.A. Akindahunsi, Biochemical changes in cassava products (flour \& gari) subjected to Saccharomyces cerevisae solid media fermentation, Food Chem.,2003, 8, 599-602.

24 U.O. Pius, E.A.C. Cemaluk, O.L. Nnamdi and E.P. Madus, Tannins and other phytochemicals of the Samanaea saman pods and their antimicrobial activities. The 34th Annual International Conference of the Chemical Society of Nigeria (CSN), 2011, 155-162.

25 A. Ozkaya, H. Ciftci, O. Yilmaz, A. Zafer Tel, E. Cil and B.S Cevrimli, Vitamin, trace element, and fatty acid levels of Vitex agnus-castus L., Juniperus oxycedrus L., and Papaver somniferum L. plant seeds, J. Chem., 2013, 845743, 1-4

26 J. Zhou and D. Han, Proximate, amino acid and mineral composition of pupae of the silkworm Antheraea pernyi in China, J. Food Comp. Anal., 2006, 19, 850-853.

27 K.A. Cockell, M.R. L'Abbe and B. Belonje, The concentrations and ratio of dietary calcium and phosphorus influence development of nephrocalcinosis in female rats, J. Nutr., 2002, 132, 252-256.

28 J.Z. Schneider, The calcium to phosphorus ratio as related to mineral metabolism, Int. J. Orthodon., Oral Surg. Radiogr., 1930, 16, 277-285

29 FAO/WHO, 1973, Energy and Protein Requirements, FAO/WHO, Rome, Italy.

30 FAO/WHO, 1973, Energy and Protein Requirements, FAO/WHO, Rome, Italy.

31 F. Musieba, S. Okoth, R.K. Mibey, S. Wanjiku and K. Moraa, Proximate composition, amino acids and vitamins profile of Pleurotus citrinopileatus Singer: an indigenous mushroom in Kenya, Amer. J. Food Tech., 2013, 8, 200-206.

32 FAO/WHO/UNU, 1985, Energy and Protein Requirements, Report of a joint $\mathrm{FAO} / \mathrm{WHO} / \mathrm{UNU}$, Expert consultation, World Health Organisation Technical Rep. Ser. 724, WHO, Geneva.

33 I. Nehdi, Characteristics, chemical composition and utilisation of Albizia julibrissin seed oil, Ind. Crops Prod., 2011, 33, 30-34

34 J-R. Riba, B. Esteban, G. Baquero, R. Puig and A. Rius, Temperature dependence of density and viscosity of vegetable oil, Biomass Bioenergy, 2012, 42, 164-171

35 S. Fatnassi, I. E. Nehdi and H. Zarrouk, Chemical composition and profile characteristics of Osage orange Maclura pomifera (Rafin.) Schneider seed and seed oil, Ind. Crops Prod., 2009, 29, 1-8.33.

36 C.S. $\mathrm{Ku}$ and S.P. Mun, Characterization of seed oils from fresh Bokbunja (Rubus coreanus Miq.) and wine processing waste, Bior. Tech., 2008, 99, 2852-2856.

37 S.J. Shin, Vitamin E modulates radiation-induced oxidative damage in mice fed a high-lipid diet, J. Biochem. Mol. Biol., 2003, 36, 190-195.

38 N. Habila, H.M. Inuwa, I.A. Aimola, A.S. Agbaji, Z. Ladan, R. Shangodare, I.S. Williams, O.B. Odjobo and E. Ogabiela, Variation of fatty acids and vitamin $E$ composition in seed oils of some plant species, J. Plant Studies, 2012, 1, 55-60. 